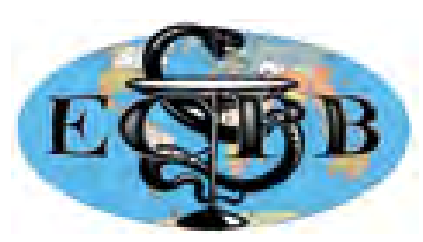

УДК 613.955 /. 96: (371.72+371.78)
“ЕКСПЕРИМЕНТАЛЬНА ТА КЛІНІЧНА ФІЗІОЛОГІЯ І БІОХІМІЯ”

"EXPERIMENTAL AND CLINICAL PHYSIOLOGY AND BIOCHEMISTRY"

Науково-практичний журнал/Scientific-practical journal

Наукові статті / Research article

ECPB 2018, 4(84): 24-30. https://doi.org/

\title{
Peculiarities of Children's Adaptation to the Systematic Educational Activity in Different age Groups
}

\author{
N.V. MOSKVIAK, I.G. MUDRA \\ Danylo Halytskyi Lviv National Medical University, Lviv, Ukraine \\ E-mail: natalimoskviak@ukr.net,irymudra@gmail.com
}

Introduction. The study of psycho-physiological characteristics of pupils as indicators of the course of the adaptation process plays a crucial role in the hygiene of training and education of schoolchildren, since the transition from preschool to school is accompanied by changes in the stereotype of behavior as well as the formation of new forms in the conditions of the increased emotional and mental load [1-3]. The analysis of psycho-physiological changes caused by biological or social factors of the environment provides an opportunity to obtain sufficient clear criteria for assessing the favorable and unfavorable environmental impacts on the children's organisms $[4,5]$.

It should be noted that peculiarities of school education which are determined by the combined influence of physical, emotional, communicative, mental load, raise complex requirements for the child's personality and its adaptive resources. At the time of admission to school and during the initial assimilation of its requirements, adaptation disorders may be characterized by the formation of neurotic reactions, disruptions in learning activities or the appearance of symptoms that go beyond the normal response to stress [6,7]. According to the results of numerous studies, it has been established that the individual and psychological characteristics of the process of thinking and creative abilities of an individual play an extremely important role in the process of adaptation [8].

As it has been mentioned above, the study of peculiarities of the adaptation of the child's organism to a new micro-social environment at the initial stage of education based on monitoring their psycho-functional and psychological indicators, makes it possible to identify measures to optimize the course of adaptation to school.

The purpose of our research was to study the mental level of children's development (MDLC) and to provide the hygienic assessment of schoolchildren's adaptation at primary school of Lviv general educational establishments, depending on the age of the beginning of systematic training (from 6 and 7 years-old) based on the results of the complex psychological and psychophysiological research that will allow to detect initial changes in the state of health of children at the initial stage of education as well as to prevent the occurrence of school "maladaptation".

Materials and methods. MDLC evaluation is based on the study of the following mental activities as analysis, classification and generalization. The method of MDLC evaluation is intended for the examination of mental capabilities of children from 7 to 11 years-old and includes 4 subtests, each of them consists of 10 verbal tasks: I - shows a child's ability to analyze the essential features of objects and phenomena; II - a child's ability to classify concepts; 
III - a child's ability to analyze by analogy; IV - determines a child's ability to generalize on the basis of inductive findings [9].

Correction tables by V. Anfimov [10] were used to determine the stability and switching of the attention. The general emotional state of children was assessed by a comprehensive school anxiety test based on a series of indicators (frustration of the desire to succeed, the fear of self-expression, the fear of the situation of testing knowledge, low physiological resistance to stress, the fear of relationships with a teacher) [11].

For the purpose of studying the levels of intellectual development, school-related anxiety and attention parameters, two groups of pupils were formed according to the age of school enrollment (6 and 7 years-old respectively); both boys and girls were included in each group. 200 children had their attention parameters and intellectual development characteristics studied (100 children from each investigated group). The estimation of school-related anxiety was conducted on the basis of testing of 150 pupils of primary school age $(75$ children from each investigated group). Selective samples were formed according to the health level (I and II health groups), age, sex, economical and social characteristics (qualitative representation) and sufficiency in the quantitative relation (quantitative representation) of the investigated children. The calculation of the exact children's calendar age was done according to the recommendations of experts from WHO (www.easycalculation.com/date-day/age-calculator.php). The group of 6 year-old children included schoolchildren from 5 years 6 months to 6 years 5 months and 29 days. The age group of 7 year-olds consisted of children from 6 years 6 months to 7 years 5 months and 29 days. Findings were obtained by using "MS Office Excel 2003" and "Statistica 6.0". The average reliable difference in each age group was examinated due to commonly known medical - biological methods of attainments by t-criteria of Student threshold value of statistical credibility under $\mathrm{P}<0.05$ limits.

Results and discussion. On the basis of testing conducted for MDLC evaluation, the main operations of thinking were determined and the following results were obtained: the high level was observed in $20.7 \pm 3.5 \%$ of children, the average level in $66.2 \pm 4.2 \%$ and low in $13.1 \pm 2.9 \%$ (Fig. 1). According to the results of the analysis of MDLC distribution in the certain age groups of children, it was determined that $25.3 \pm 5.0 \%$ of 6 year-old children had a high level and this figure was lower by $10.7 \%$ in 7 year-old children $(\mathrm{P}>0.05)$

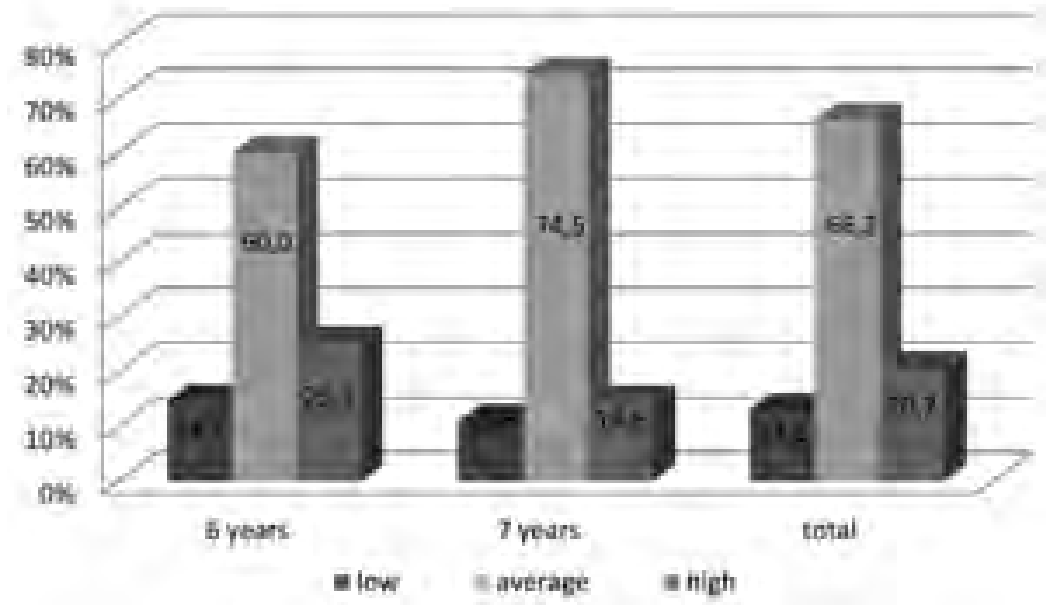

Fig. 1. Distribution of 6-7 year-old children by the level of their mental development

Low MDLC is observed in $14.7 \pm 4.1 \%$ of 6 year-old schoolchildren and $10.9 \pm 4.2 \%$ of 7 year-olds accordingly, that is, the proportion of 7 year-old children with a low MDLC is lower by $4.0 \%$ as compared to a similar indi- 
cator in 6 year-olds. The average MDLC was determined in $60.0 \pm 5.6 \%$ of children admitted to school at the age of 6 . In children who started systematic schooling at the age of 7 , the proportion of individuals with an average level of mental development is $74.5 \pm 5.9 \%(\mathrm{P}>0.05)$. Consequently, according to the test results, no reliable differences were revealed between schoolchildren aged 6-7 according to the levels of their mental development.

One of the obligatory elements of the effective learning process of primary schoolchildren is the level of formation of attention parameters. The major properties of attention involved the study of the attention stability and switching in 6-7 year-old children, taking into account the distribution by gender (Table 1). The attention stability and attention switching, as the basic properties of this mental process, are evaluated by the duration of focusing on one of the objects or a type of activity and the ability to shift focus to another object or work in connection with the need to solve a new task. Overall, attention switching represents the ability to orient quickly in a difficult situation and is almost always accompanied by some nervous tension which is caused by some volitional effort $[10,12]$.

Table 1

Distribution of 6-7 year-old children by the levels of the main properties of attention

\begin{tabular}{|c|c|c|c|c|c|c|}
\hline \multirow{3}{*}{$\begin{array}{l}\text { Groups of } \\
\text { children }\end{array}$} & \multicolumn{6}{|c|}{ Attention properties } \\
\hline & \multicolumn{3}{|c|}{ Stability } & \multicolumn{3}{|c|}{ Switching } \\
\hline & 1 & 2 & 3 & 1 & 2 & 3 \\
\hline $\begin{array}{c}\mathrm{I}-6 \text { years } \\
\text { Boys } \\
n-50\end{array}$ & $20,0 \pm 5,6$ & $0,0 \pm 6,9$ & $20,0 \pm 5,6$ & $0 \pm 0$ & $70,0 \pm 6,5^{*}$ & $30,0 \pm 6,5$ \\
\hline $\begin{array}{l}\text { Girls } \\
\text { n-50 }\end{array}$ & $18,0 \pm 5,4$ & $52,0 \pm 7,1$ & $30,0 \pm 6,5$ & $24,0 \pm 6,0$ & $42,0 \pm 6,7$ & $34,0 \pm 6,6$ \\
\hline $\begin{array}{c}\text { II - } 7 \text { years } \\
\text { Boys } \\
n-50\end{array}$ & $12,0 \pm 4,6$ & $72,0 \pm 6,3$ & $16,0 \pm 5,2$ & $0 \pm 0$ & $48,0 \pm 7,1^{*}$ & $52,0 \pm 7,1^{*}$ \\
\hline $\begin{array}{l}\text { Girls } \\
\text { n-50 }\end{array}$ & $16,0 \pm 5,2$ & $56,0 \pm 7,0$ & $28,0 \pm 6,3$ & $0 \pm 0$ & $28,0 \pm 6,3$ & $72,0 \pm 6,3^{* *}$ \\
\hline
\end{tabular}

Note: 1 - Low level; 2 - average level; 3 - high level; ${ }^{*} \mathrm{P}<0.05 ; 3$. ${ }^{* *} \mathrm{P}<0.001$.

According to the results of the study of attention properties in children of the junior school age, it has been established that the stability of attention in both sex-age groups is mainly within the average level and there is no reliable difference between the indicators. Among boys who started schooling at the age of 7, the proportion of the average level is higher than that of girls of this age group and 6 year-old schoolchildren by 16.0 and $12.0 \%$, respectively $(\mathrm{P}>0.05)$. The proportion of children with high levels of attention stability is slightly higher among girls of both age groups.

Indicators of attention switching are similarly characterized by the dominance of the average level among the total number of the surveyed schoolchildren. At the same time, among 6-year-old girls, the proportion of individuals with the average level $(42.0 \pm 6.7 \%)$ is significantly lower $(\mathrm{P}<0.05)$ than among boys $(70.0 \pm 6.5 \%)$. Low level of attention switching was observed only in $24.0 \pm 6.0 \%$ of 6 year-old girls. Among the 7 year-old girls, the highest value of the level of attention switching was observed in $72.0 \%$. The proportion of 7 year-old children with a high level of attention switching is significantly higher than that of 6 -year-old schoolchildren among boys by $22.0 \%(\mathrm{P}<0.05)$ and among girls by $38.0 \%(\mathrm{P}<0.001)$. Similar results were obtained by other researchers [13]. Apparently this is due to the fact that in the younger age group, the attention switching as a process has not been completely formed yet and is still in the process of its development. 
The assessment of general anxiety among pupils indicates that a significant part of the surveyed (28.7\%) is characterized by high and elevated levels of anxiety (Fig. 2, Fig. 3).

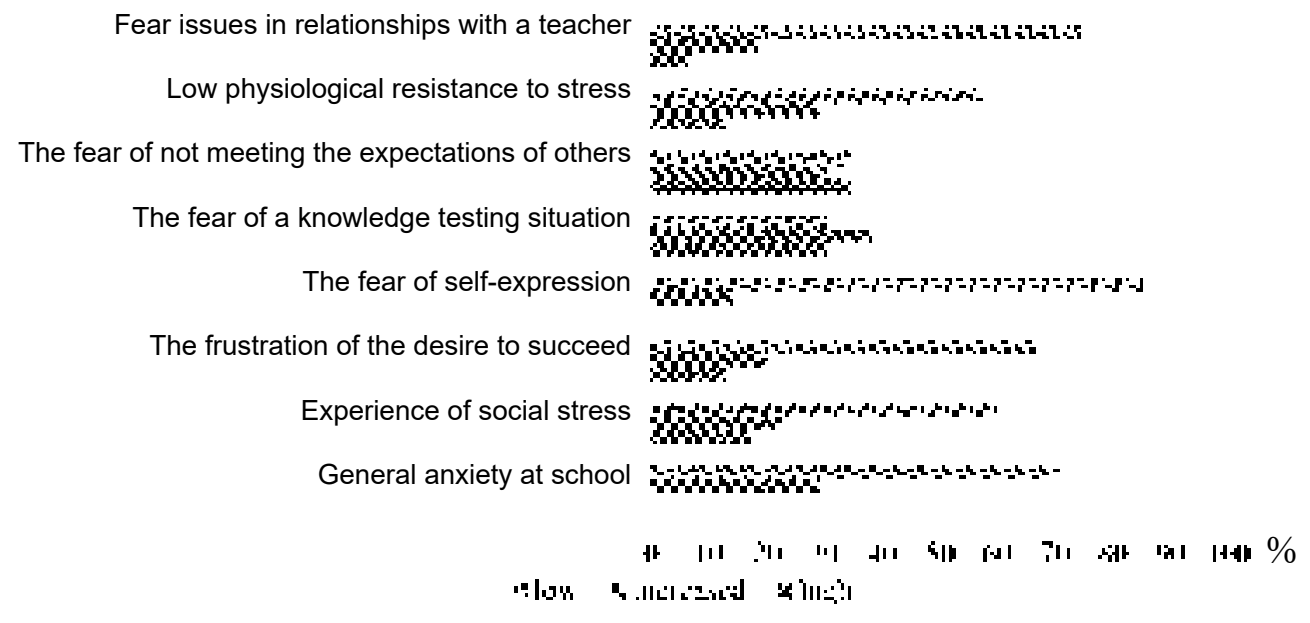

Fig. 2. Levels of school anxiety indicators for 6-year-old children

Fear issues in relationships with a teacher

Low physiological resistance to stress

The fear of not meeting the expectations of others 1000 -

The fear of a knowledge testing situation $40+4$

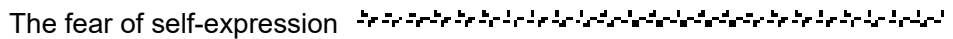

The frustration of the desire to succeed

Experience of social stress

General anxiety at school 20

$$
\begin{aligned}
& \text { 山 أ }
\end{aligned}
$$

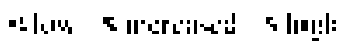

Fig. 3. Levels of school anxiety indicators for 7 year-old children

For children who started their education at the age of six this figure is 29.3 $\pm 5.3 \%$, at the same time, this value is 2.3 times lower in their 7 year-old classmates $(\mathrm{P}<0.05)$. But in general, the majority of children of both age groups $(72.7 \%)$ have a low level of anxiety with some fluctuations from $70.7 \pm 5.3 \%$ in 6-year-olds to $74.7 \pm 5.8 \%$ in 7-year-olds. The high level of anxiety was observed only in seven year-old schoolchildren $(12.7 \pm 4.5 \%)$. Thus, the overall emotional state of children can be considered satisfactory.

In general, the high level of anxiety caused by the experience of social stress was characteristic for $17.3 \%$ of the surveyed children of a junior school and only limited by six year-old pupils. There was no significant difference in the indicators of the increased level of anxiety $(22.7 \pm 4.8 \%$ among 6 year-old pupils and $23.6 \pm 5.7 \%$ among 7 year-olds). The majority of children had a low level of anxiety according to this indicator (6 year-olds $-60.0 \pm 5.6 \%$, and in 7 -year-olds it was significantly higher $-76.4 \pm 5.7 \%$ ), which positively favors the development of social contacts with peers. 
In $72.0 \%$ of junior schoolchildren there was a low level of anxiety due to the frustration of the desire to succeed, but the proportion of 7 year-old children was 1.2 times higher $(78.2 \pm 5.6 \%)$ than the same indicator for six year-olds $(66.7 \pm 5.4 \%)$. The high level of anxiety was established only in the first-class pupils at the age of six, which to some extent can prevent children from developing their needs and achieving high results. The establishment of the dominance of low level of anxiety was associated with the fear of self-expression: in 6 year-olds $-85.3 \pm 4.1 \%$, in 7 year-olds $-100.0 \%$ which can be considered as a positive result of our study. The elevated level of anxiety was established in $14.7 \pm 4.1 \%$ of children who began to study at school at the age of six.

The fear of a situation of testing knowledge played a special part: an increased level of anxiety was felt by $48.7 \%$ of schoolchildren, with fluctuations from $38.6 \pm 5.6 \%$ in 6-year-olds to $61.8 \pm 6.5 \%$ in 7 year-old children $(\mathrm{P}<0.05)$. That is, the older age group responded more emotionally to the process of testing knowledge or performing control assignments. A high level was observed in $30.7 \pm 5.3 \%$ of 6 year-old pupils and was absent in 7 year-olds. As to the low level, the indicator practically did not differ from each other. Almost in equal proportions, both in general and in certain age groups there was an indicator that characterized the fear of not meeting the expectations of others $(\mathrm{P}>0.05)$.

The obtained data have indicated a low physiological resistance to stress and in different age groups, the level of the indicator is not significantly different (for 6 year-olds $-57.4 \pm 5.7 \%$, for 7 year-olds $-61.8 \pm 6.5 \%$, respectively). This feature of the psychophysiological functions of the child's body reduces the adaptability to stressful situations. The elevated level was observed in $29.3 \pm 5.2 \%$ of 6 year-old children and $38.2 \pm 6.5 \%$ in 7 year-olds. Among the six year-old pupils of first-graders there was $13.3 \pm 3.9 \%$ of individuals with a high level of anxiety.

It is interesting to study the issue of fear in relationships with the teacher as an indicator that reflects the negative aspects of communicating with adults at school and reduces the child's ability to succeed in studying. The low level of anxiety prevailed in $68,7 \%$, but this figure was slightly higher in 6 year-old children and was $74,6 \pm 5.0 \%$ as compared to $61,8 \pm 6,5 \%$ in 7 year-olds. The increased level of anxiety was higher among those pupils who started schooling at the age of $7(38,2 \pm 6,5 \%)$, while in the 6 -year-olds their proportion was lower by $18,5 \%(\mathrm{P}<0,05)$. At the same time a high level of anxiety was established exclusively in the age group of 6 year-old children that can be explained by a lack of functional maturity, comparing with 7-year-olds.

Thus, the analysis of the obtained data reflects the presence of high anxiety levels by a number of indicators, especially in children who began their education at the age of six, which can cause stress formation and school maladjustment. The reliable difference on the level of school anxiety by a number of criteria among the surveyed age groups indicates a more adequate course of social and psychological adaptation among schoolchildren who started their schooling at the age of 7 .

According to the results of our previous studies, a method of complex hygienic estimation of adaptation of primary school pupils was used which included the examination of the functional status of the cardio-vascular system with subsequent objective assessment according to the value of the cardiovascular system adaptation potential. The existence of the inverse probable median strength correlation between the level of adaptation potential and school-related anxiety was established (the group of 6 year-olds $\mathrm{r}=-0.36, \mathrm{P}<0.01$; the group of 7 year-olds $\mathrm{r}=-0.45, \mathrm{P}<0.01$ ). This demonstrates that the level of anxiety becomes lower when the adaptation potential approaches the satisfactory value [14].

It can be argued that the individual characteristics of responses among the 7 year-old children before the study allow to support a more stable and 
adequate level of psychophysiological functions over a long period of time as compared to their 6 year-old classmates.

Conclusions. 1 . Taking into account the results of the children's evaluation of mental development, the tendency towards the predominance of individuals with an average level of mental development is observed among pupils admitted to school at the age of seven as well as a smaller proportion of children of this age group with low levels that shows the equal opportunities of children of both age groups to master the curriculum.

2. The obtained attention indicators show that pupils of both age groups are able to focus enough attention on a certain object or a type of activity for a long time, but the level of attention switching is more formed in 7 year-old schoolchildren.

3. The overall emotional state of children assessed by a comprehensive school anxiety test regardless of age can be considered satisfactory. But by a number of indicators (frustration of the desire to succeed, the fear of self-expression, the fear of situation of testing knowledge, the low physiological resistance to stress, the fear issues in relationships with a teacher), the high level of anxiety is established exclusively in children who began to study at school at the age of six. The 7 year-old schoolchildren are likely to have higher levels of anxiety as to the following indicators such as the fear of the situation of testing knowledge and the fear of having a relationship with a teacher.

Thus, it can be argued that the individual characteristics of responses among the 7 year-old children can support a more stable and adequate level of psycho-physiological functions over a long period of time as compared to their 6-year-old classmates. The revealed basic psycho-physiological peculiarities of primary schoolchildren needs conducting observations of their dynamic during all process of studying at primary school and revealing the measures of optimization of adaptation at school, especially among 6-year-old children.

\section{REFERENCES (ПОСИЛАННЯ)}

1. Басанець ЛМ, Іванова ОI, Кулагіна ТВ, Токаренко ОМ. Психофункціональні показники першокласників у динаміці навчання. Педагогічні науки: теорія, історія, інноваційні технології. 2014;6:97-105 (Basanets LM, Ivanova OI, Kulagina TV, Tokarenko OM. Psychofunctional indicators of first-graders in the dynamics of training. Pedagogical sciences: Theory, History, Innovative Technologies. 2014;6:97-105).

2. Твердохліб MM, Дяченко CB. Адаптація дітей до навчальної діяльності в сучасних загальноосвітніх навчальних закладах. Наука і освіта. 2014;8:182-5 (Tverdokhlib MM, Dyachenko SV. Adaptation of children to educational activity in modern general educational institutions. Science and Education. 2014. 2014;8:182-5).

3. Прокоб'єва ОО, Аносова ДI. Соціально-психологічна адаптація молодших школярів до навчання у середній школі засобами арт-терапії. Молодий вчений. 2016;12:268-72 (Prokofieva OO, Anosova DI. Socio-psychological adaptation of junior pupils to study at secondary school by means of art therapy. Young Scientist. 2016;12:268-72).

4. Белих НА. Особливості психоемоційного статусу дітей, які виховуються в соціально дезадаптованих сім'ях. Современная педиатрия. 2008;1:23-7 (Belich NA. Features of the psycho-emotional status of children who are brought up in socially disadapted families. Modern Pediatrics. 2008;1:23-7).

5. Басанець ЛМ, Іванова OI. Вплив мікросоціального середовища на фрізичний розвиток і стан здоров'я дітей та підлітків. Довкілля та здоров'я. 2010;1:52-4 (Basanets LM, Ivanova OI. The influence of microsocial environment on physical development and health of children and adolescents. Environment and Health. 2010;1:52-4).

6. Яиула МC, Нянковський СЛ. Синдром шкільної дизадаптацї: актуальність проблеми в першокласників. Педіатрия, акушерство та гінекологія. 2008;1:17-9 (Yatsula MS, Nyankousky SL. Syndrome of school dysadaptation: relevance of the problem in first-graders. Pediatrics, Obstetrics and Gynecology. 2008;1:17-9).

7. Періг IM, Медвідь OB. Особливості адаптації першокласників до навчання в школі. Актуальні задачі сучасних технологій: матеріали 5-ї міжнар. наук.-техн. конф. молодих учених та студентів; м. Тернопіль, 17-18 лист. 2016; Тернопіль. 2016;358-9 (Perig IM, Medvid OV. Features of adaptation of first-graders to study at school. Current problems of modern technologies: materials of the V International Scientific and Technical Conference of Young Scientists and Students; 2016 November 17-18; Ternopil, 2016;358-9). 
8. Фурлан АВ. Психодіагностика інтелекту в системі диференціації навчання. Київ: Освіта; 1993. 195 с. (Furman AV. Psychodiagnostics of intelligence in the system of training differentiation. Kyiv: Osvita, 1993. 195 p.)

9. Партико T, Кучерява Г. Методика визначення рівня розумового розвитку дітей $1-5$ класів (7-11 років). Львів: ЛОНМІО; ВНТЛ;1998. 12 с. (Partyko T., Kucheryava G. Methodology for determining the level of mental development of children of 1-5 grades (7-11 years old). Lviv: LONMIO; VNTL, 1998. 12 p.)

10. Максиленко С, Терлецька Л, Главник О. Увага дитини. Київ: Мікрос-СВС; 2004. 111 с. (Maksymenko S, Terletska L, Glaunyk A. Attention of the child. Kyiv: Micros-CBC, 2004. 111 p.)

11. Максиленко C, Главник О. Адаптація дитини до школи. Київ: Мікрос-СВС; 2003. 110 c. (Maksimenko S, Glaunyk O. Adaptation of the child to school. Kyiv: Micros-CBC, 2003. 110 p.)

12. Максиленко C, Маценко В, Главник О. Розвиток пізнавальних процесів дитини. Київ: Мікрос-CBC, 2003. 108 c. (Maksymenko S, Matsenko V, Glynnik A. Development of cognitive processes of a child. Kyiv: Micros-CBC; 2003. 108 p.)

13. Федориів OЄ, Лучишин НЮ. Особливості адаптаційних можливостей серцево-судинної системи у дітей із синдромом гіперактивності з дефіцитом уваги. Актуальні питання педіатрії, акушерства та гінекології. 2010;1:50-3 (Fedortsiv OY, Luchyshyn NYu. Features of the adaptive capacity of the cardiovascular system in children with hyperactivity syndrome with attention deficit. Actual Questions of Pediatrics, Obstetrics and Gynecology. 2010;1:50-3).

14. Москвяк НВ. Комплексний метод вивчення та оцінки процесу адаптації. Гігієна населених місць: зб. наук. праць. Київ, 2013;61:290-4 (Moskviak NV. The method of comprehensive study and evaluation of adaptation. Hygiene of Populated Places: collection of research papers. Kyiv, 2013;61:290-4).

Стаття надійшла до редколегії 16.11.2018

\title{
RESEARCH ARTICLE
}

\section{Peculiarities of Children's Adaptation to the Systematic Educational Activity in Different age Groups}

\author{
N.V. MOSKVIAK, I.G. MUDRA \\ Danylo Halytskyi Lviv National Medical University, Lviv, Ukraine \\ E-mail: natalimoskviak@ukr.net,irymudra@gmail.com
}

Background. The assessment of the intellectual development and the hygienic estimation of adaptation have been conducted among the primary schoolchildren of the city of Lviv in connection with the age of starting their education ( 6 and 7 years old) on the basis of attention and general emotional state estimation by means of the complex test of school-related anxiety that included a number of parameters (the frustration of the need to succeed, the fear of self-expression, the fear of the situation of knowledge testing, the low physiologic stress resilience and issues of fear in the pupil-teacher relationships).

Materials and methods. 200 pupils were involved in testing the attention and intellectual development parameters. The estimation of school-related anxiety was done on the basis of tests in which 150 primary schoolchildren took part.

Results. According to the results of the intellectual development estimation of the children it has been determined that the number of children with the average intellectual development was higher among the children that started school at the age of 7 ( 74.5 versus $60.0 \%$ in the younger age group); the number of children with the level of the intellectual development was lower in the older age group (10.9\% versus $14.7 \%$ respectively). The study of attention switching as an ability to get oriented fast in a complex situation and to solve complicated tasks has demonstrated that, according to this parameter, the level of the psychological development of 7 year-olds was higher than their 6 year-old classmates. The reliable difference of the level of school-related anxiety parameters among the studied children of both age groups has shown the more adequate course of adaptation of those pupils who started school education at the age of 7 .

Conclusion. The obtained results have determined the necessity of the optimization of the course of adaptation of younger pupils to the systematic school activity, especially the 6-year olds, on the basis of psycho-physiological functions and psycho-emotional monitoring status as the objective characteristics of the formation and condition of adaptation.

Key words: primary schoolchildren, adaptation, intellectual development, attention parameters, school-related anxiety. 